
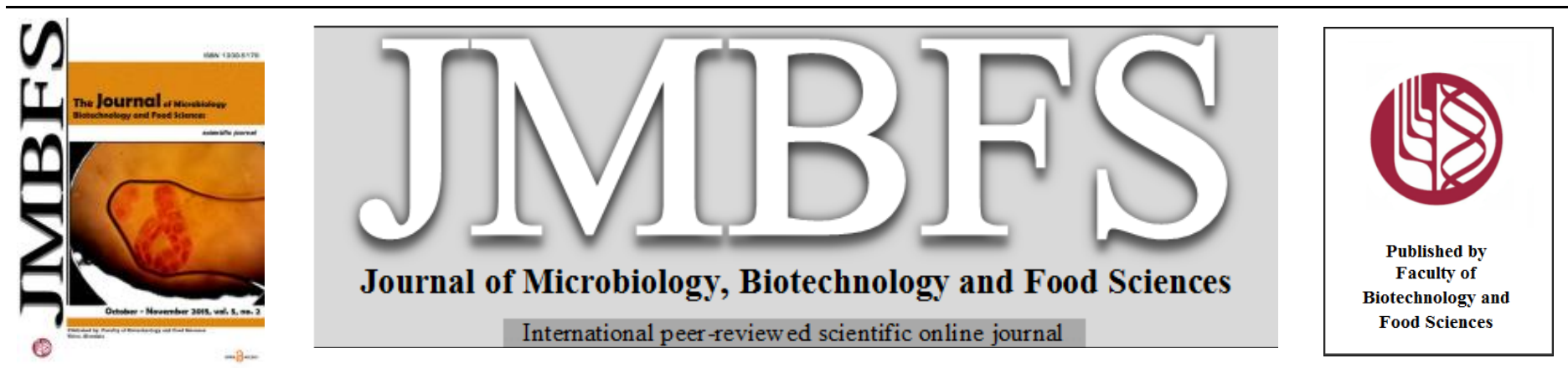

\title{
DIFFERENCES OF ANTIBACTERIAL ACTIVITY SPECTRA AND PROPERTIES OF BACTERIOCINS, PRODUCED BY GEOBACILLUS SP. BACTERIA ISOLATED FROM DIFFERENT ENVIRONMENTS
}

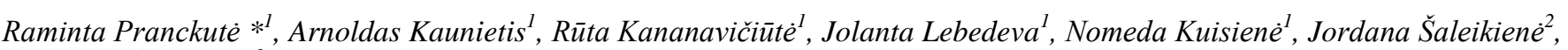 \\ Donaldas Čitavičius ${ }^{l}$
}

Address(es): Raminta Pranckutè,

${ }^{1}$ Vilnius University, Faculty of Natural Sciences, Department of Microbiology and Biotechnology, Chiurlionio str. 21/27, LT-03100, Vilnius, Lithuania, phone number: +37052398210 .

${ }^{2}$ National Public Health Surveillance Laboratory (NPHSL), Zholyno str. 36, Vilnius, Lithuania, LT-10210.

*Corresponding author: raminta18@gmail.com

doi: 10.15414/jmbfs.2015.5.2.155-161

\section{ARTICLE INFO}

Received 27. 3. 2014

Revised 28. 4. 2015

Accepted 7. 7. 2015

Published 1. 10. 2015

Regular article open $\partial_{\text {AcCESS }}$

\section{ABSTRACT}

Ability of bacteriocins to inhibit pathogenic bacteria may depend on the environment inhabited by the producing strain. However, there are just few reports on bacteriocin-producing thermophilic bacteria from unconventional environments. Therefore, in this work we investigated differences in antibacterial activity spectra of microorganisms isolated from two different environments: the oil wells (first collection) and surface soil above the oil pools (second collection).

All strains were Gram-positive, rod-shaped, thermophilic and endospore forming bacteria. Using spot-on-lawn method we have demonstrated that strains from the second collection possess higher and broader antibacterial activity spectra than first collection strains. Furthermore, all strains were active against at least 1 of 19 tested pathogenic bacteria. Analysis of antibacterial compounds has shown that all of them were stable in broad temperature and $\mathrm{pH}$ ranges, sensitive to proteolytic enzymes, proving their proteonaceus nature. They were all secreted during the exponential growth phase and active against closely related thermophilic bacteria, which suggest that these substances are most likely bacteriocins. Most of the bacteriocins had molecular masses under $20 \mathrm{kDa}$. Plasmid isolation and elimination experiments suggest that bacteriocins are most likely chromosome-encoded.

Our results confirm the differences between antibacterial spectra of bacteriocins produced by bacterial strains isolated from different environmental niches.

Keywords: Antibacterial activity spectrum, bacteriocin, endospore, growth analysis, thermophile

\section{INTRODUCTION}

Bacteriocins are naturally ribosomally synthesized antimicrobial peptides or proteins, usually possessing the narrow antibacterial activity spectrum against bacterial strains closely related to the producer (Abriouel $\boldsymbol{e t}$ al., 2011, Gálvez $\boldsymbol{e t}$ al., 2008). These proteonaceous molecules are produced by various Grampositive and Gram-negative bacterial strains, often during the regulation of bacterial population size by the mechanism of quorum sensing or during the stressful conditions (Fontaine and Hols, 2008). The activity of this group of molecules against foodborne and pathogenic bacteria opens wide opportunities for bacteriocin application (Anisimov and Amoako, 2006; Desriac et al., 2010; Lohans and Vederas, 2012; Montesinos, 2007; Piper et al., 2009; Settanni and Corsetti, 2008).

Bacteriocins produced by Gram-positive bacteria are mainly classified by their size, structure and modifications, like the presence of disulphide bonds, carbohydrate or lipid moieties and modified or unusual amino acids (Lohans and Vederas, 2012; Heng et al., 2007; Nissen-Meyer et al., 2010; Maqueda et al., 2007; Lee and Kim, 2011). Most of described bacteriocins are secreted by the lactic acid bacteria (LAB) (Gálvez et al., 2008, Khan et al., 2008). Little is known about bacteriocins, produced by Gram-positive thermophilic bacteria, although the interest in these microorganisms is increasing due to their resistance to high temperatures which may be relevant to the protection of heat-treated food products. The application of bacteriocins from thermostable microorganisms may help to reduce the usage of chemical substances and/or heat (Sit and Vederas, 2008). Although there are few reports about cytotoxicity of bacteriocins, produced by some streptococci, enterococci or Escherichia coli strains to mammalian cell lines, but usually only in higher concentrations than required for their biological activity against bacterial cells (Paiva et al., 2012; Lagos, 2007), most bacteriocins are not toxic for eukaryotic cells (Gálvez et al., 2008), Therefore, bacteriocins of thermophilic bacteria can also be applied in medicine, agriculture and veterinary (Abriouel et al., 2011; Anisimov and Amoako, 2006;
Desriac et al., 2010; Lohans and Vederas, 2012; Mantovani et.al., 2011; Montesinos, 2007).

Up to now bacteriocins from Streptoccoccus thermophilus strains constitute the majority of investigated thermophilic bacteria bacteriocins (Fontaine and Hols, 2008; Aktypis et al., 1998; Aktypis and Kalantzopoulos, 2003; Aktypis et al., 2007; Ivanova et al., 1998; Gilbreth and Somkuti, 2005; Kabuki et al., 2007; Marciset et al., 1997; Mathot et al., 2003; Villani et al., 1995). Meanwhile there are only few described bacteriocins, produced by Geobacillus sp. bacteria: six bacteriocins of low molecular mass, secreted by G. stearothermophilus bacteria (Yule and Barridge, 1976; Sharp et al., 1979; Pokusaeva et al., 2009); two bacteriocins of $G$. thermoleovorans strains (Novotny and Perry, 1992); Toebicin, secreted by G. toebii HBB-218 strain (Özdemir and Biyik, 2011) and two lantibiotics, produced by G. thermodenitrificans NG80-2 strain (Garg et al., 2012). All these bacteriocins are characterized by the thermostability and resistance to $\mathrm{pH}$ changes.

Bacteriocins of thermophilic bacteria have many perspective qualities, as described above. Specific antibacterial activity spectrum is also a very important feature and may depend on the species habitat. Accordingly, in this work we investigated two collections of thermophilic bacteria, isolated from Lithuanian oil wells and the surface soil above the oil pools. The goal of this study was to evaluate the influence of antibacterial compounds secreted by thermophilic bacteria from two different environments on the antibacterial activity spectra Antibacterial activity spectra and physicochemical properties of antibacterial substances produced by some of the isolates were determined in this work, as these criteria are the most important aiming to evaluate the possibilities of the bacteriocins' application in the food and other industries. 


\section{MATERIAL AND METHODS}

\section{Bacterial strains and culture conditions}

In this work we used Geobacillus sp. bacterial strains from the culture collection of the Department of Microbiology and Biotechnology of Vilnius University (Vilnius, Lithuania). The strains of the first collection were isolated from
Lithuanian oil wells, and strains of the second collection - from the surface soil above the oil pools. All isolated strains are listed in Table 1.

Mainly two media were used for cultivation of the bacterial strains: enriched Nutrient Broth (NB) and mineral modified M9 medium (mM9) (growth media were prepared as described at "Fermentas molecular biology catalog \& product application guide", 2002-2003). Cultures were grown aerobically on agar media at $60^{\circ} \mathrm{C}$, or in liquid media at $55^{\circ} \mathrm{C}$, with $180 \mathrm{rpm}$ agitation.

Table 1 Isolated strains from the first and second collections

\begin{tabular}{lll}
\hline \hline Collection (number of strains) & Source & Strains \\
\hline \hline \multirow{2}{*}{ First collection $(68)$} & Lithuanian & $1 \mathrm{~K} ; 2 ; 3 ; 3 \mathrm{~K} ; 3 \mathrm{~N} ; 4 ; 4 \mathrm{~K} ; 5 ; 6 ; 7 ; 8 ; 9 ; 10 ; 11 ; 12 ; 13 ; 15 ; 16 ; 17 ; 18 ; 19 ; 21 ; 22 ; 22 \mathrm{~N} ; 23 ;$ \\
& oil wells & $24 ; 25 ; 26 ; 27 ; 28 ; 29 ; 29 \mathrm{~A} ; 30 ; 31 ; 32 \mathrm{~A} ; 32 \mathrm{~B} ; 32 \mathrm{C} ; 32 \mathrm{D} ; 33 ; 34 ; 35 \mathrm{~A} ; 35 \mathrm{~B} ; 35 \mathrm{C} ; 36 \mathrm{~A} ;$ \\
& & $36 \mathrm{~B} ; 51 ; 62 ; 64 ; 65 ; 67 ; 69 ; 70 ; 71 ; 72 ; 73 ; 74 ; 75 ; 77 ; 78 ; 79 ; 80 ; 82 ; 84 ; 85 ; 86 ; 87 ; 88 ; 89$ \\
\hline \multirow{2}{*}{ Second collection $(68)$} & Surface soil & $1.1 ; 1.2 ; 1.3 ; 1.4 ; 1.5 ; 1.7 ; 1.81 ; 1.82 ; 1.9 ; 1.10 ; 1.11 ; 1.12 ; 1.14 ; 1.16 ; 1.17 ; 2.3 ; 2.4 ; 2.7 ;$ \\
& above the & $3.2 ; 4.1 ; 4.2 ; 4.3 ; 4.5 ; 4.7 ; 4.8 ; 4.81 ; 4.9 ; 4.10 ; 4.11 ; 4.12 ; 4.21 ; 4.22 ; 5.1 ; 5.2 ; 5.3 ; 5.6 ; 5.7 ;$ \\
& oil pools & $5.8 ; 5.9 ; 5.10 ; 6.1 ; 6.2 ; 6.3 ; 6.4 ; 6.5 ; 6.10 ; 6.11 ; 6.12 ; 6.13 ; 6.14 ; 7.1 ; 7.2 ; 7.3 ; 7.41 ; 7.42 ;$ \\
\hline \hline
\end{tabular}

\section{Phenotypic analysis of isolated strains}

Gram-Staining and $\mathrm{KOH}$ test were performed as described by Chandra and Man (Chandra et al., 2011), except Safranin (Merck Millipore, Darmstand, Germany) was used instead of Carbol Fuchsin in Gram Staining. Formation of endospores of isolated strains was determined by Schaeffer-Fulton Stain (Gerhardt $\boldsymbol{e t}$ al. 1981). Growth temperature range of the strains was determined by growing strains in liquid NB medium with agitation, at temperatures differing by $5^{\circ} \mathrm{C}$ Optical Density (wavelength of $590 \mathrm{~nm}$ ) of cultures was measured during the growth.

\section{$16 \mathrm{~S}$ rDNA sequence analysis}

Genomic DNA of bacterial strains was extracted as described by Sambrook and Russel (2001). PCR amplification of $16 \mathrm{~S}$ rDNR genes was done using universal primers 27F (5'-AGATTTGATCCTGGCTCAG-3') and 1492R (5'TACGGYTACCTTGTTCGACTT-3'). PCR products were purified from $1 \%$ agarose gel and sequenced at the Sequencing Center of the Institute of Biotechnology (Vilnius, Lithuania). Obtained sequences were aligned using Lasergene 6 Program package (DNAStar, USA). in silico data analysis was performed using the NCBI Blast program (http://blast.ncbi.nlm.nih.gov/Blast.cgi).

\section{Determination of antibacterial activity spectrum}

Strains isolated in this work were tested against each other in order to determine their capability to inhibit the growth of closely related thermophilic bacteria. The antagonistic interactions of isolated strains were determined using the spot-onlawn method (Çadirci and Çitak, 2005; Kormin et al., 2001; Moraes et.al., 2010). The tested strains were grown overnight at $60^{\circ} \mathrm{C}$ in the middle of Petri dish with an NB agar medium. Then the layer of NB agar media with inoculated other presumed sensitive strain was poured on the top of the grown culture. The agar media with inoculated strain was prepared by adding $20 \%(\mathrm{v} / \mathrm{v})$ of culture inoculum $\left(\mathrm{OD}_{590 \mathrm{~nm}}=1.8\right)$ into an appropriate agar medium. Plates were incubated at $60^{\circ} \mathrm{C}$ for $6-12 \mathrm{~h}$

Evaluation of antibacterial activity against closely related species was also determined by spot-on-lawn method, as described above. Determination of antibacterial activity against pathogenic bacteria was carried out by the same method at the National Public Health Surveillance Laboratory (NPHSL) in Lithuania. Closely related thermophilic bacteria species and pathogenic bacteria used for the evaluation of antibacterial activity spectrum are listed in Table 2.

Table 2 Thermophilic and pathogenic bacteria strains used for the determination of antibacterial activity spectrum of isolated strains

\begin{tabular}{ll}
\hline \hline Thermophilic bacteria & Pathogenic bacteria \\
\hline \hline Geobacillus stearothermophilus NUB36187 (9A11) (BGSC) & Streptococcus pyogenes ATCC 19615 \\
Geobacillus uzenensis VKM B-2229 & Steptococcus pneumoniae ATCC 6305 \\
Geobacillus subterraneus VKM B-2226 & Enterococcus faecalis ATCC 2912 \\
Geobacillus thermocatenulatus VKM B-1259 ${ }^{\mathrm{T}}$ & Enterococcus faecium 402-3/03 \\
Geobacillus thermoleovorans DSM 5366 & Haemophilus influenzae ATCC 10211 \\
Geobacillus thermodenitrificans DSM 466 & Staphylococcus aureus ATCC 25923 \\
Geobacillus lituanicus N-3 & Staphylococcus haemolyticus P903 \\
& Staphylococcus epidermidis ATCC 12228 \\
& Pseudomonas aeruginosa ATCC 27853 \\
Escherichia coli ATCC 25922 \\
Klebsiella pneumoniae DSM 30104 \\
Yersinia enterocolitica ATCC 9610 \\
Salmonella typhimurium ATCC 14028 \\
Salmonella enteritidis ATCC 13076 \\
Listeria monocytogenes ATCC 19117 \\
Listeria innocua ATCC 33090 \\
Bacillus cereus DSM 12001 \\
Bacillus subtilis ATCC 6633 \\
Clostridium perfringens ATCC 13124 \\
\hline \hline
\end{tabular}

Legend: ${ }^{T}$ - indicates the type strain. Culture collections: ATCC - American Type Culture Collection, BGSC - Bacillus Genetic Stock Center (Ohio, USA); DSMZ - German Collection of Microorganisms and Cell Cultures (Braunschweig, Germany); VKM - All-Russian Collections of Microorganisms (Moscow, Russia)

\section{Evaluation of antibacterial activity}

Antimicrobial activity of supernatants of tested cultures was determined by agar well diffusion assay. Agar medium with indicator strain was prepared adding $20 \%$ of indicator strain inoculums $\left(\mathrm{OD}_{590 \mathrm{~nm}}=1.8\right)$ into the agar $\mathrm{NB}$ media Geobacillus stearothermophilus NUB36187 (9A11) was used as indicator strain. $0.5 \mathrm{~cm}$ diameter wells were made using sterile plastic pipette tips in the agar media with inoculated sensitive strain. Culture samples were centrifuged and the serial two-fold dilutions of cell free supernatants were made, using $50 \mathrm{mM}$ Tris$\mathrm{HCl}$ (Sigma-Aldrich, Taufkirchen, Germany) (pH 7.5) buffer. The volume of 100 $\mu \mathrm{l}$ of every dilution was poured into the prepared wells and plates were incubated at $60^{\circ} \mathrm{C}$ temperature for $6-8$ hours. The antibacterial activity was expressed in terms of arbitrary units (AU), as a maximum dilution which produced a clearly visible inhibition zone. The unit of antimicrobial activity (AU) was defined as the reciprocal of the highest level of dilution resulting in a clear zone of growth inhibition (Hyronimus et.al., 1998; Vera Pingitore et al., 2007)

\section{Sodium dodecyl sulfate polyakrylamide gel electrophoresis (SDS-PAGE) and zymogram preparation}

Crude protein extracts of cultures with antimicrobial activity were gained after precipitation with ammonium sulfate (Roth, Karlsruhe, Germany) to $70 \%$ saturation (Rosenberg, 2005). These extracts were examined using SDS-PAGE method (Vera Pingitore et al., 2007). In order to determine the molecular mass 
of antimicrobial compounds we prepared the zymogram: part of PAGE gel was fixed in fixing solution (20\% isopropanol (Roth, Karlsruhe, Germany), $10 \%$ acetic acid (Merck Millipore, Darmstand, Germany), 70\% water) for two hours, after that the gel was washed with distilled water for at least two hours on a shaker, changing water every 15-20 minutes. Then the gel was placed in a Petri dish and overlaid with agar NB media with indicator strain (media preparation is described above). Prepared zymogram was incubated at $60^{\circ} \mathrm{C}$ temperature overnight. Clear zone in the zymogram indicates the position of antibacterially active protein in the gel.

\section{Physicochemical analyses of crude protein extracts}

\section{Enzymatic treatment}

Crude protein extracts were treated with the following enzymes at fina concentration of $1 \mathrm{mg} \mathrm{ml}^{-1}$ : proteinase $\mathrm{K}$, trypsin and $\alpha$-chymotrypsin (Merck Millipore, Darmstand, Germany); pronase E, pepsin, $\alpha$-amylase and lipase (Sigma-Aldrich, Taufkirchen, Germany). All enzymes were dissolved in buffers as recommended by the suppliers. Sample and enzyme mixtures were incubated at $37^{\circ} \mathrm{C}$ for 2 hours. Remaining antibacterial activity was determined in terms of $\mathrm{AU} \mathrm{ml} \mathrm{m}^{-1}$. Untreated crude protein extracts and enzyme solutions were taken as respective controls (Tiwari and Srivastava, 2008)

\section{pH treatment}

Aiming to determine bacteriocin stability within various $\mathrm{pH}$ range, crude protein extracts were mixed with series of $100 \mathrm{mM}$ buffers (Sigma-Aldrich, Taufkirchen, Germany) with $\mathrm{pH}$ from 2.0 to 10.0 (ratio $1: 1$ ) and incubated at $37^{\circ} \mathrm{C}$ for two hours. Buffers were chosen according to $\mathrm{pH}$ value of the samples. $\mathrm{pH}$ was restored with $0.5 \mathrm{M}$ Tris- $\mathrm{HCl}$ buffer, $\mathrm{pH}$ 7.5. The remaining activity in $\mathrm{pH}$ treated samples was determined by agar well diffusion assay (Tiwari and Srivastava, 2008). Samples of crude protein extracts in Tris- $\mathrm{HCl}$ buffer $(50 \mathrm{mM}, \mathrm{pH} 7.5)$ were taken as respective controls $(\mathrm{K})$.

\section{Sensitivity to various temperatures}

In order to determine the impact of temperature changes on antibacterial activity of bacteriocins, crude protein extracts were incubated at various temperatures: 60 $70,80,90,100$ and $121^{\circ} \mathrm{C}$ for 30 minutes. The remaining antibacterial activity was evaluated by agar well diffusion assay and expressed in arbitrary units (AU). Samples were also kept at $+4^{\circ} \mathrm{C}$ temperature for 2 weeks and 1 week at room temperature $\left(20^{\circ} \mathrm{C}\right)$ to evaluate the stability of bacteriocin activity. The untreated samples were taken as respective controls (K) (Lee et al., 2001).

\section{Ion exchange chromatography}

Ion exchange chromatography was performed at the Institute of Biochemistry (Vilnius, Lithuania), using Resource $\mathrm{Q}$ ion exchange column and liquid chromatography system AKTA Purifier (GE Healthcare, Helsinki, Finland). Gradient was created using Tris- $\mathrm{HCl}(\mathrm{pH} 7.5,50 \mathrm{nM})$ buffer and the same buffer with $1 \mathrm{M} \mathrm{NaCl}$.

\section{Screening for presence of plasmids and plasmid elimination}

Plasmid DNA extraction was performed by alkaline extraction method as described by Sambrook and Russel (2001). The presence of plasmids and size of superspiralized small plasmids was determined by agarose gel electrophoresis (Sambrook and Russel, 2001). For linearization of the detected plasmids we used 21 restriction endonucleases (RE): AatII, Acc65I, BamHI, Bsp143I, Eco88I, EcoRI, Eco33I, HincII, HindIII, NcoI, NdeI, NheI, NotI, PaeI, PstI, PvuI, SacI, SalI, SmaI, SspI, XbaI (Thermo Fisher Scientific, Vilnius, Lithuania). Size of linearized plasmids was determined by comparission of agarose gel electrophoresis (Sambrook and Russel, 2001) with DNA fragments standard GeneRulerTM DNA Ladder Mix (Thermo Fisher Scientific, Vilnius, Lithuania).

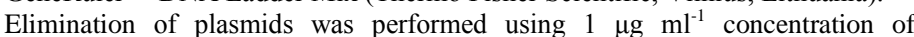
Novobiocin (INC Biochemicals, California, USA) in the culture medium (NB) (Hyronimus et.al., 1998)

\section{RESULTS}

\section{Phenotypic analysis of isolated strains}

Results of Gram staining and $\mathrm{KOH}$ test have shown that all isolated strains from both collections are Gram-positive. Use of Schaeffer-Fulton stain has confirmed that all isolated strains also are endospore forming, rod-shaped bacteria. Analysis of the growth temperature range has shown that all strains from the first collection are obligate thermophiles with the growth range from $50^{\circ} \mathrm{C}$ to $80^{\circ} \mathrm{C}$ Analysis of the growth of the second collection strains has revealed that from 68 strains 49 were obligate thermophiles (growth range from $50^{\circ} \mathrm{C}$ to $80^{\circ} \mathrm{C}$ ) and 19 strains were facultative thermophiles (growth range from $30^{\circ} \mathrm{C}$ to $70^{\circ} \mathrm{C}$ ).

\section{$16 \mathrm{~S}$ rDNA sequence analysis}

Strains 3, 11, 18, 32A and 36 A (Pokusaeva et al., 2009) and strains 9, 17, 19, 28, 30 and 31 are identified by 16 rDNA analysis and DNA hybridization as Geobacillus stearothermophilus, also strain 22 identified as G. vulcani in previous studies (unpublished results). Results of $16 \mathrm{~S}$ rDNA analysis of other isolated strains were inconclusive and require deeper investigation, such as DNADNA hybridization. Strain N-3 is a type strain of Geobacillus lituanicus species, described in our laboratory (Kuisiene et al., 2004). According to the results of 16 rDNA analysis, 12.1 strain belongs to Geobacillus thermoglucosidasius and 6.10 strain to Geobacillus thermodenitrificans species (unpublished results).

\section{Antibacterial interactions between the isolated strains}

For the analysis of antibacterial interactions between isolated strains we used spot-on-lawn method. Due to the enormous amounts of isolated strains and experiments required to analyze their antagonistic interactions, we were not able to test all of the isolated strains. From the first collection 43 strains were analyzed. Results of the analysis are presented in Figure 1.

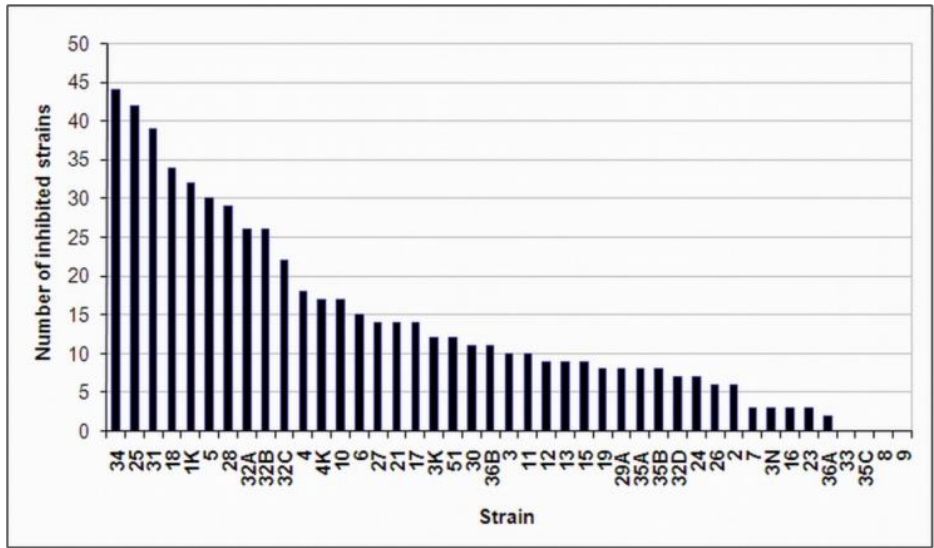

Figure 1 Antibacterial interactions between 43 isolated strains from the first collection. Symbols: - number of inhibited strains from the 43 strains of the first collection

We have determined that all tested strains were sensitive to at least one antibacterial compound, produced by the tested strains. 40 strains were secreting antibacterial substances. 10 strains, which constitute about $23 \%$ of the investigated strains of the first collection, were active against more than $50 \%$ of tested strains. However, 4 strains did not inhibit any of the tested strains (Fig 1). Antibacterial interactions between 21 strains from the second collection were analyzed. Results are presented in Figure2.

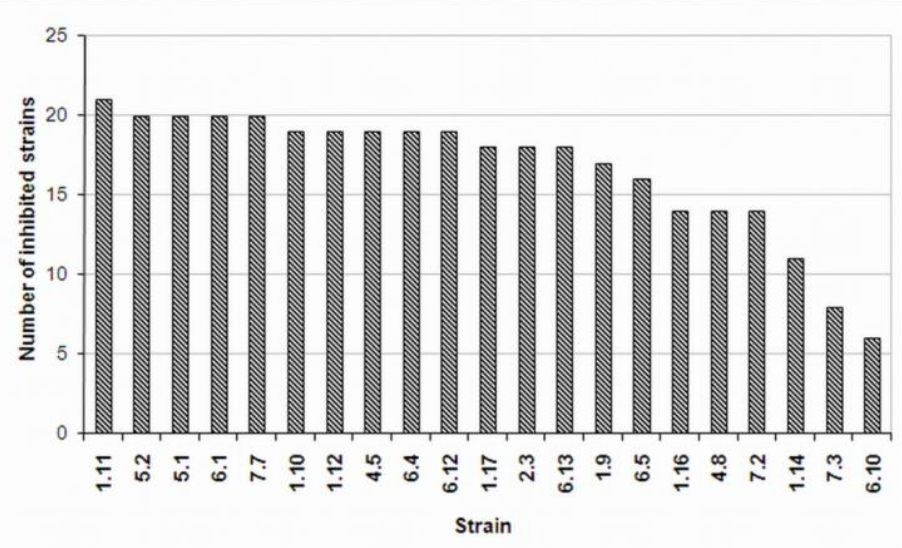

Figure 2 Antibacterial interactions between 21 strains from the second collection: - number of inhibited strains from the 21 strains of the second collection

It was shown that all tested strains were able to inhibit at least 6 other tested strains. 19 strains, which constitute about $90 \%$ of the investigated strains from the second collection, inhibited the growth of more than $50 \%$ of tested strains. It should be noted that three strains $(1.11,6.12$ and 7.7) inhibited their own growth.

\section{Determination of antibacterial activity spectrum}

Antibacterial activity of isolated strains against closely related thermophilic bacteria species was also evaluated. It was shown that 52 of 68 strains $(76.5 \%)$ from the second collection were active against Geobacillus stearothermophilus 
NUB36187 (9A11) strain. From 43 tested strains of the first collection, 33 (76.7\%) were also active against 9A11 strain. Two strains from the first collection (32A and 32B) were also tested against other Geobacillus sp. bacteria (Tab 2). 32A strain was active against G. uzenensis VKM B-2229 ${ }^{\mathrm{T}}, G$ subterraneus VKM B-2226 ${ }^{\mathrm{T}}$, G. thermocatenulatus VKM B- $1259^{\mathrm{T}}$ and $G$. thermoleovorans DSM $5366^{\mathrm{T}}$ strains. G. uzenensis was the most sensitive to antibacterial compound, secreted by $32 \mathrm{~A}$ strain, while G. thermodenitrificans DSM $466^{\mathrm{T}}$ was resistant to it. 32B strain possessed the antibacterial activity against $G$. lituanicus $\mathrm{N}-3$ strain.

101 isolated strains (56 strains from the first and 45 strains from the second collection) were also tested against 19 pathogenic bacteria strains (Tab 2). It was shown that all 101 tested strains were able to inhibit the growth of at least 1 pathogenic bacteria strain (Fig 3).

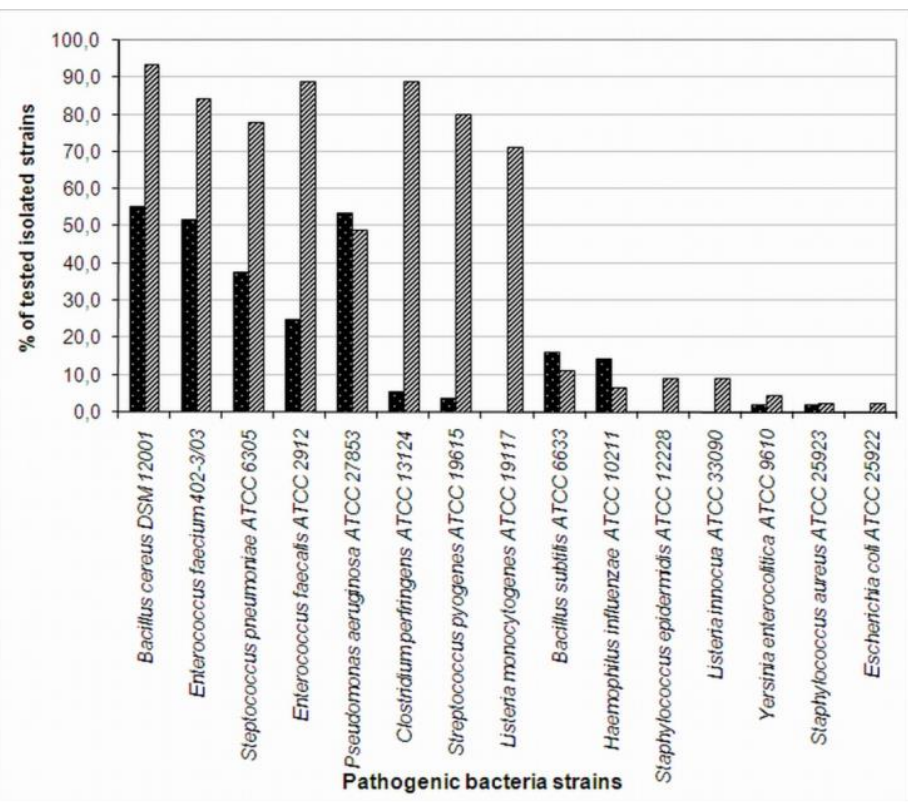

Figure 3 Antibacterial activity of 101 isolated strains against pathogenic bacteria: - number of strains $\mathrm{m}$ the first collection, active against pathogenic bacteria; - number of strains from the second collection, active against pathogenic bacteria
More than $50 \%$ of the investigated strains were active against B. cereus DSM 12001 (72.3\%), E. faecium 402-3/03 (66.3\%), S. pneumoniae ATCC 6305 (55.4\%), E. faecalis ATCC $2912(53.5 \%)$ and P. aeruginosa ATCC 27853 (51.5\%). 42.6, 37.6 and $31.7 \%$ of strains were active against $C$. perfringen ATCC 13124, S. pyogenes ATCC 19615 and L. monocytogenes ATCC 19117 respectively. None of the tested strains were able to inhibit 4 pathogenic bacteria strains (S. haemolyticus P903, K. pneumoniae DSM 30104, S. typhimurium ATCC 14028 and S. enteritidis ATCC 13076).

Strains from the second collection inhibited the growth of 15 pathogens, while strains of the first collection were active only against 11 pathogenic bacteria strains. Data presented in Figure 3. show that considerably more strains from the second collection were active against B. cereus DSM 12001 (55.6\% of tested strains from the first collection and $93.3 \%$ of strains from the second collection), E. faecium 402-3/03 (51.8\% and 84.4\%), S. pneumoniae ATCC 6305 (37.5\% and $77.8 \%)$, E. faecalis ATCC 2912 (25.0\% and 88.9\%), C. perfringens ATCC $13124(5.4 \%$ and $88.9 \%)$ and S. pyogenes ATCC 19615 (3.6\% and 80.0\%). Moreover, only the strains from the second collection possessed the antibacterial activity against L. monocytogenes ATCC 19117, S. epidermidis ATCC 12228, L innocua ATCC 3309 and E. coli ATCC 25922 (Fig 3).

\section{Physicochemical analyses of secreted antibacterial compounds}

According to the results of the antibacterial activity spectrum against other collection strains (Fig 1 and Fig 2) and pathogenic bacteria (Fig 3), 11 strains (17, $18,22,25,30,31,32 \mathrm{~A}, 32 \mathrm{~B}, 1 \mathrm{~K}, 4.7$ and 9.1) were chosen for the more detailed investigation of their secreted antibacterial compounds. Crude protein extracts of investigated strains were used for the phenotypic analysis.

Crude protein extracts of 9 strains $(17,18,22,25,30,31,32 \mathrm{~A}, 32 \mathrm{~B}$ and $1 \mathrm{~K})$ were treated with different $\mathrm{pH}$ values. Results, presented in Table 3 , show that al examined antibacterially active substances are stable in the $\mathrm{pH}$ range from 3 to 10.

Table 3 Remaining antibacterial activity of the crude protein extracts after treatment with different $\mathrm{pH}$ values. Remaining antibacterial activity was determined by agar well diffusion assay

\begin{tabular}{lllllllllll}
\hline \hline \multirow{2}{*}{$\mathbf{p H}$} & \multicolumn{7}{l}{ Remaining antibacterial activity (\%) of the crude protein extracts from isolated strains } \\
\cline { 2 - 10 } & $\mathbf{1 7}$ & $\mathbf{1 8}$ & $\mathbf{2 2}$ & $\mathbf{2 5}$ & $\mathbf{3 0}$ & $\mathbf{3 1}$ & $\mathbf{3 2 A}$ & $\mathbf{3 2 B}$ & $\mathbf{1 K}$ \\
\hline \hline 3 & 50 & 100 & 30 & 100 & 100 & 100 & 100 & 100 & 100 \\
\hline 4 & 50 & 100 & 30 & 100 & 100 & 100 & 100 & 100 & 100 \\
\hline 5 & 50 & 100 & 30 & 100 & 60 & 100 & 100 & 100 & 100 \\
\hline 6 & 50 & 100 & 30 & 100 & 60 & 100 & 100 & 100 & 100 \\
\hline 7 & 50 & 100 & 60 & 100 & 60 & 100 & 100 & 100 & 100 \\
\hline 8 & 70 & 100 & 100 & 100 & 100 & 100 & 100 & 100 & 100 \\
\hline 9 & 80 & 100 & 60 & 100 & 100 & 100 & 100 & 100 & 100 \\
\hline 10 & 100 & 100 & 30 & 100 & 100 & 100 & 100 & 100 & 100 \\
\hline $\mathrm{K}$ & 100 & 100 & 100 & 100 & 100 & 100 & 100 & 100 & 100 \\
\hline \hline
\end{tabular}

Legend: $\mathrm{K}$ - control

The influence of different temperatures on the antibacterial activity was investigated using crude protein extracts from 11 strains: 17, 18, 22, 25, 30, 31, $32 \mathrm{~A}, 32 \mathrm{~B}, 1 \mathrm{~K}, 4.7$ and 9.1. Results presented in Table 4 suggest that most of 11 antibacterial compounds are relatively thermostable and retain antibacterial activity in broad temperature range up to $100^{\circ} \mathrm{C}$. These substances also remain completely stable after prolonged storage at +4 and $20^{\circ} \mathrm{C}$. Crude protein extracts from 9 strains $(17,18,22,25,30,31,32 \mathrm{~A}, 32 \mathrm{~B}$ and $1 \mathrm{~K})$ were treated with different proteolytic enzymes and $\alpha$-amylase (Tab 5).

Table 4 Remaining antibacterial activity of the crude protein extracts after treatment with different temperatures. Remaining antibacterial activity was determined by agar well diffusion assay

\begin{tabular}{|c|c|c|c|c|c|c|c|c|c|c|c|}
\hline \multirow{2}{*}{ Temperature $\left({ }^{\circ} \mathrm{C}\right)$} & \multicolumn{11}{|c|}{ Remaining antibacterial activity $(\%)$ of the crude protein extracts from isolated strains } \\
\hline & 17 & 18 & 22 & 25 & 30 & 31 & 32A & 32B & $1 \mathrm{~K}$ & 4.7 & 9.1 \\
\hline 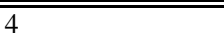 & 100 & 100 & 100 & 100 & 100 & 100 & 100 & 100 & 100 & 100 & 100 \\
\hline 20 & 100 & 100 & 100 & 100 & 100 & 100 & 100 & 100 & 100 & 100 & 100 \\
\hline 60 & 100 & 100 & 100 & 100 & 100 & 100 & 100 & 100 & 100 & 100 & 100 \\
\hline 70 & 25 & 100 & 100 & 100 & 100 & 80 & 75 & 50 & 100 & 100 & 100 \\
\hline 80 & 25 & 75 & 100 & 100 & 90 & 80 & 60 & 25 & 50 & 100 & 100 \\
\hline 90 & 25 & 50 & 100 & 0 & 90 & 70 & 60 & 13 & 50 & 100 & 100 \\
\hline 100 & 25 & 25 & 100 & 0 & 60 & 40 & 50 & 0 & 0 & 0 & 0 \\
\hline 121 & 0 & 0 & 0 & 0 & 0 & 0 & 0 & 0 & 0 & 0 & 0 \\
\hline $\mathrm{K}$ & 100 & 100 & 100 & 100 & 100 & 100 & 100 & 100 & 100 & 100 & 100 \\
\hline
\end{tabular}


Table 5 Remaining antibacterial activity of the crude protein extracts after treatment with different enzymes. Remaining antibacterial activity was determined by agar well diffusion assay

\begin{tabular}{|c|c|c|c|c|c|c|c|c|c|}
\hline \multirow{2}{*}{ Enzyme } & \multicolumn{9}{|c|}{ Remaining antibacterial activity $(\%)$ of the crude protein extracts from isolated strains } \\
\hline & 17 & 18 & 22 & 25 & 30 & 31 & 32A & 32B & $1 \mathrm{~K}$ \\
\hline Proteinase $\mathrm{K}$ & 0 & 50 & 0 & 100 & 100 & 0 & 0 & 0 & 13 \\
\hline$\alpha$-chymotrypsin & 0 & 50 & 20 & 100 & 50 & 33 & 30 & 0 & 6 \\
\hline$\beta$-chymotrypsin & 100 & 75 & 20 & 100 & 100 & 50 & 50 & 66 & 3 \\
\hline Papain & 0 & 50 & 20 & 100 & 0 & 0 & 33 & 50 & 3 \\
\hline Tripsin & 0 & 100 & 40 & 80 & 100 & 40 & 100 & 13 & 3 \\
\hline Ficin & 0 & 100 & 66 & 100 & 100 & 100 & 50 & 100 & 6 \\
\hline$\alpha$-amylase & 0 & 75 & 66 & 100 & 100 & 100 & 100 & 13 & 13 \\
\hline $\mathrm{K}$ & 100 & 100 & 100 & 100 & 100 & 100 & 100 & 100 & 100 \\
\hline
\end{tabular}

Legend: $\mathrm{K}$ - control

All antibacterial compounds, except the ones secreted by strains 30 and 25, were sensitive to the treatment with proteinase K. Antibacterial substance of strain 30 was sensitive to papain and $\alpha$-chymotrypsin, while the substance of the strain 25 was only slightly sensitive to trypsin. Three antibacterial substances, secreted by strains $17,32 \mathrm{~B}$ and $1 \mathrm{~K}$, were almost completely inactivated by the treatment with $\alpha$-amylase. These results indicate that bacteriocins secreted by these three strains may contain carbohydrate moieties in their structure. Also, antibacteria compounds of 5 strains $(17,22,30,31,32 \mathrm{~A})$ had lost their activity after treatment with DTT (Dithiothreitol) (data not shown), which means that disulphide bonds are necessary for the activity of the five investigated bacteriocins.

\section{Determination of molecular masses of antibacterial compounds}

Using SDS-PAGE and zymography methods we determined that most of the investigated bacteriocins had molecular masses between 5 and $20 \mathrm{kDa}$ : strain 17 - 6.8 kDa, strain $22-6.2 \mathrm{kDa}$, strain $30-5.6 \mathrm{kDa}$; strain $31-7.1 \mathrm{kDa}$; strain $32 \mathrm{~A}-7.2 \mathrm{kDa}$, strain $32 \mathrm{~B}-\sim 15 \mathrm{kDa}$; strain $35 \mathrm{C}-12$ and $<10 \mathrm{kDa}$; strain 4.7 $\sim 7 \mathrm{kDa}$, strain $9.1-7$ and $20 \mathrm{kDa}$. Two strains $(9.1$ and $1 \mathrm{~K})$ secreted 2 bacteriocins each. Strain 18 secreted 3 antibacterial substances with molecular masses of 2, 12 and $\sim 100 \mathrm{kDa}$. Only strains 18,25 and $1 \mathrm{~K}$ secreted antibacteria compounds or aggregates of high molecular mass of $\sim 100, \sim 60$ and $\sim 200 \mathrm{kDa}$ respectively. It should be noted that after ion-exchange chromatography of the strain $1 \mathrm{~K}$ crude protein extract, two antibacterially active peaks were obtained indicating that this strain produces two bacteriocins or a two-peptide bacteriocin, where each of the peptides possesses an antibacterial activity. This was partially confirmed by the fact that we have obtained two clear zones in the zymogram, compatible with 60 and $120 \mathrm{kDa}$ molecular mass markers (data not shown). Antibacterial compound secreted by strain $1 \mathrm{~K}$ may contain carbohydrate moieties as the compound is sensitive to the treatment with $\alpha$-amylase. The example of such two-peptide bacteriocin could be thermophilin 580, produced by Streptococcus thermophilus 580 strain (Mathot et al., 2003).

\section{Screening for the presence and curing of plasmids}

Isolated strains were screened for the possession of plasmids. From 36 strains of the first collection, 12 strains $(3,3 \mathrm{~K}, 4,5,9,13,18,19,22,32 \mathrm{~B}, 32 \mathrm{D}, 33)$ had one large $(>50 \mathrm{~kb})$ plasmid each. Since all detected plasmids were similar in size, three strains - 3, 18 and 19 - were randomly chosen for further analysis. Based on the results of $16 \mathrm{~S}$ rDNA analysis and DNA-DNA hybridization from previous studies, these strains were assigned to G. stearothermophilus species (Pokusaeva et al., 2009). The plasmids of the chosen strains were named pGS3, pGS18 and pGS19 respectively. Sizes of the plasmids from strains 3, 18 and 19 were evaluated by determining the sizes of restriction fragments. Plasmids pGS3 and pGS19 were about $52 \mathrm{~kb}$ in size. Plasmid pGS18 had molecular mass of about 62 $\mathrm{kb}$.

Plasmids were detected only in three strains from the second collection. One strain (1.12) had two plasmids: one small (1.5 kb), named pGTG5, and one larger $(>12 \mathrm{~kb})$. Two strains (6.10 and 7.7) had three plasmids each: one large (>12 kb) and to small $(\sim 3.5$ and $\sim 3.0 \mathrm{~kb})$. Aiming to determine possible cytoplasmic heredity of bacteriocins, we performed plasmid elimination experiments. After the plasmid elimination, strains have retained antibacterial activity.

\section{DISCUSSION}

There is a growing interest in thermophilic bacteria bacteriocins as they are characterized by the better stability, which is a favorable quality in the food industry. As most of bacteriocins, the ones produced by thermophilic bacteria are characterized by specific antimicrobial activity spectra which may vary depending on the environment of the producing species. Accordingly, in this work we analyzed two collections of thermophilic bacteria, isolated from different environmental niches: the Lithuanian oil wells or the surface soil above the oil pools. Environmental sources of isolated strains differ in several aspects such as temperature and the main nutrition sources. The temperature in the oil well is about $80^{\circ} \mathrm{C}$, so it is not surprising that the results of growth dependence on temperature have shown all strains from the first collection being obligate thermophiles, while the second collection contained obligate and facultative thermophiles.

Type of the main nutritional substance in the environment determines the variety of microorganisms that can assimilate it and colonize the niche. The main nutritional carbon source in the oil well is hydrocarbonates, while in the surface soil the main source is carbohydrates. Hydrocarbonates are not such a favorable carbon source for most microorganisms as carbohydrates, so the variety of bacterial species in the oil well should be poorer than in the surface soil. This fact can explain the results of antibacterial interactions between isolated strains and against pathogenic bacteria, which have shown that strains, isolated from the surface soil above the oil pools (second collection), possess higher and broader antibacterial activity spectra against other strains of the collection as well as against pathogenic bacteria than strains isolated from the oil wells (first collection). The reason for this could be that strains from the surface soil (second collection) evolved broader antibacterial spectrum during the evolution due to the possibility of higher interaction rate with other bacterial species compared with the strains living deep in the oil pools where the number of different bacterial species is considerably lower.

Physicochemical analysis of antibacterial compounds secreted by 11 strains has shown that all analyzed substances were sensitive to proteolytic enzymes, which indicates their proteinaceous nature. They were all secreted during the exponential growth phase and active against closely related thermophilic bacteria species. These results suggest that the investigated antibacterial substances are most likely bacteriocins. Moreover, the investigated bacteriocins remain stable in broad temperature and $\mathrm{pH}$ ranges. These properties and specific antibacterial activity spectrum against pathogenic bacteria, makes them favorable for the application in the food industry, veterinary or medicine.

Aiming to determine the location of bacteriocin encoding genes, strains were screened for the presence of plasmids. It was shown than the investigated collections also differ in the frequency of plasmids and their sizes. $33 \%$ of strains from the first collection had large plasmids $(>50 \mathrm{~kb})$, which coincides with the results obtained by Ståhl (1991), as three of our investigated strains had been previously identified as G. stearothermophilus (Pokusaeva et al., 2009) Meanwhile only in three strains from the second collection small plasmids were detected. However, it is not known if the number and size of plasmids may be dependent on the inhabitation environment of the strain. Moreover, strains have not lost their antibacterial activity after the elimination of plasmids, which suggests that bacteriocin encoding genes of Geobacillus sp. bacteria are more likely localized in the chromosome. It may be because more stable genes of bacteria living in higher temperatures are localized in the chromosome and plasmids of thermophilic bacteria more often encode genes associated with resistance to high temperature (Ståhl, 1991).

The study revealed that after a long storage (a year or more) at $-70^{\circ} \mathrm{C}$ or $-20^{\circ} \mathrm{C}$, the isolated strains lose part of their antibacterial activity (data not shown). For example, strains, active against all or more than a half of the collection strains, after year and a half storage at $-70^{\circ} \mathrm{C}$ were able to inhibit only one or few collection strains. Unfortunately, causes of this phenomenon are unknown. Considering the properties of the investigated bacteriocins, which are beneficial for their application, efforts will be made to examine the causes of the activity loss

\section{CONCLUSION}

The differences in the antibacterial activity spectra, optimal growth temperature, frequency and size of plasmids among strains isolated from Lithuanian oil wells and the surface soil above the oil pools show that the environmental niche has an influence on the properties of bacteriocins. This fact highlights the niches where bacteriocin producers with even broader antibacterial activity spectra may be found. Perspective physicochemical properties and the spectra of inhibited pathogenic bacteria species makes bacteriocins produced by Geobacillus sp bacteria even more suitable for the application in the food industry, veterinary or medicine.

Acknowledgements: This work was partially financed by the "ThermozymOS" project (Grant No. SVE-08/2011) of the Research Council of Lithuania. 


\section{REFERENCES}

ABRIOUEL, A., FRANZ, C.M.A.P., OMAR, N.B., GÁLVEZ, A. 2011. Diversity and applications of Bacillus bacteriocins. FEMS Microbiology Reviews, 35, 201-232. http://dx.doi.org/10.1111/j.1574-6976.2010.00244.x.

AKTYPIS, A., KALANTZOPOULOS, G. 2003. Purification and characterization of thermophilin ST-1, a novel bacteriocin produced by Streptococcus thermophilus ACA-DC 0001. Lait, 83, 365-378 http://dx.doi.org/10.1051/lait:2003024.

AKTYPIS, A., KALANTZOPOULOS, G., HUIS IN‘T VELD, J.H.J., TEN BRINK, B. 1998. Purification and characterization of thermophilin T, a nove bacteriocin produced by Streptococcus thermophilus ACA-DC0040. Journal of Applied Microbiology, 84, 568-576. http://dx.doi.org/10.1046/j.1365 2672.1998.00383.X.

AKTYPIS, A., TYCHOWSKI, M., KALANTZOPOULOS, G., AGGELIS, G. 2007. Studies on bacteriocin (thermophilin T) production by Streptococcus thermophilus ACA-DC 0040 in batch and fed-batch fermentation modes. Antonie van Leeuwenhoek, 92(2), 207-220. http://dx.doi.org/10.1007/s10482-007-9148-4. ANISIMOV, A.P., AMOAKO, K.K. 2006. Treatment of plague: promising alternatives to antibiotics. Journal of Medical Microbiology, 55, 1461-1675. http://dx.doi.org/10.1099/jmm.0.46697-0.

CADIRCI B.H., CITAK S. 2005. Comparison of Two Methods Used for Measuring Antagonistic Activity of Lactic Acid Bacteria. Pakistan Journal of Nutrition, 4(4), 237-241. http://dx.doi.org/10.3923/pjn.2005.237.241

CHANDRA, T.J., MANI, P.S. 2011. A study of 2 rapid tests to differentiate Gram positive and Gram negative aerobic bacteria. Journal of Medical \& Allied Sciences, 1(2), 84-85.

DESRIAC, F., DEFER, D., BOURGOUGNON, N., BRILLET, B., LE CHEVALIER, P., FLEURY, Y. 2010. Bacteriocins as Weapons in the Marine Animal-Associated Bacteria Warfare: Inventory and Potential Applications as an Aquaculture Probiotic. Marine Drugs, 8(4), 1153 1177. http://dx.doi.org/10.3390/md8041153.

FONTAINE, L., HOLS, P. 2008. The Inhibitory Spectrum Of Thermophilin 9 from Streptococcus thermophilus LMD-9 Depends on the Production of Multiple Peptides and the Activity of $\mathrm{BlpG}_{\mathrm{St}}$, a Thiol-Disulfide Oxidase. Applied and Environmental Microbiology, 1110. http://dx.doi.org/10.1128/AEM.02030-07.

GÁLVEZ, A., LÓPEZ, R.L., ABRIOUEL, H., VALDIVIA, E., OMAR, N.B. 2008. Application of Bacteriocins in the Control of Foodborne Pathogenic and Spoilage Bacteria, Critical reviews in biotechnology, 28(2), 125 152. http://dx.doi.org/10.1080/07388550802107202.

GARG, A., TANG, W., GOTO, Y., NAIR, S.K., VAN DER DONK, W.A. 2012 Lantibiotics from Geobacillus thermodenitrificans. Proceedings of the National Academy of Sciences of the United States of America, 109(14), 5241-6. http://dx.doi.org/10.1073/pnas.1116815109.

GERHARDT, P., MURRAY, R.G.E., COSTILOW, R.N., NESTER, E.W., WOOD, W.A., KRIEG, N.R., PHILLIPS, G.B. (Eds.). 1981. Manual of Methods for General Bacteriology, American Society for Microbiology, Washington D. C., 385 p. ISBN: 0914826301

GILBRETH, S.E., SOMKUTI, G.A. 2005. Thermophilin 110: A Bacteriocin of Streptococcus thermophilus ST110. Current Microbiology, 51(3), 175-182. http://dx.doi.org/10.1007/s00284-005-4540-7.

HENG, N.C.K., WESCOMBE, P.A., BURTON, J.P., JACK, R.W., TAGG, J.R 2007. The Diversity of Bacteriocins in Gram-Positive Bacteria, In: Riley MA and Chavan MA (Eds.) Bacteriocins: Ecology and Evolution, Chapter 4, SpringerVerlag Berlin Heidelberg. 160 p., p. 45-92. ISBN-13 978-3-540-36603-4. HYRONIMUS B., LE MARREC C., URDACI M.C. 1998. Coagulin, a bacteriocin-like inhibitory substance produced by Bacillus coaguans $\mathrm{I}_{4}$. Journal of Applied Microbiology, 85, 42-50. http://dx.doi.org/10.1046/j.13652672.1998.00466.x

IVANOVA, I., MITEVA, V., STEFANOVA, T., PANTEV, A., BUDAKOV, I., DANOVA, S., MONCHEVA, P., NIKOLOVA, I., DOUSSET, X., BOYAVAL P. 1998. Characterization of a bacteriocin produced by Streptococcus thermophilus 81, International Journal of Food Microbiology, 42(3), 147-158. http://dx.doi.org/10.1016/S0168-1605(98)00067-1.

KABUKI, T., UENISHI, H., WATANABE, M., SETO, Y., NAKAJIMA, H. 2007. Characterization of a bacteriocin, Thermophilin 1277, produced by Streptococcus thermophilus SBT1277. Journal of Applied Microbiology, 102 971-980. http://dx.doi.org/10.1111/j.1365-2672.2006.03159.x.

KHAN, H., FLINT, S., YU, P.-L. 2008. Enterocins in food preservation, International Journal of Food Microbiology, 141, 1-10. http://dx.doi.org/10.1016/j.ijfoodmicro.2010.03.005

KORMIN, S., RUSUL, G., RADU, S., LING, F.H. 2001. Bacteriocin-producing lactic acid bacteria isolated from traditional fermented food. Malaysian Journal of Medical Sciences, 8(1), 63-68.

KUISIENE, N., RAUGALAS, J., CHITAVICHIUS, D. 2004. Geobacillus lituanicus sp. nov. International Journal of Systematic and Evolutionary Microbiology. 54, 1991-1995. http://dx.doi.org/10.1099/ijs.0.02976-0

KUO, Y.-C., LIU, C.-F., LIN, J.-F., LI, A.-C., LO, T.-C., LIN, T.-H. 2013 Characterisation of putative class II bacteriocins identified from a non- bacteriocin-producing strain Lactobacillus casei ATCC 334. Applied Microbiology and Biotechnology,

246. http://dx.doi.org/10.1007/s00253-012-4149-2.

LAGOS R. 2007. Cytotoxic Activity of Bacteriocins Against Eukaryotic Cells Chapter 5. In Rilley M.A. and Gillor O. (Eds.) Applications in Bacteriocins Horizon Bioscience, Norfolk, U.K.,vi+218 p. ISBN: 978-1-904933-46-5 (ebook). LEE, K.H., JUN, K.D., KIM, W.S., PAIK, H.D. 2001. Partial characterization of polyfermenticin SCD, a newly identified bacteriocin of Bacillus polyfermenticus. Letters in Applied Microbiology, 32(3), 146-151. http://dx.doi.org/10.1046/j.1472-765x.2001.00876.x.

LEE, H., KIM, H.-Y. 2011. Lantibiotics, Class I Bacteriocins from the Genus Bacillus. Journal of Microbiology and Biotechnology, 21(3), 229-235.

LOHANS, C.T., VEDERAS, C. 2012. Development of Class IIa Bacteriocins as Therapeutic Agents. International Journal of Microbiology. http://dx.doi.org/10.1155/2012/386410.

MANTOVANI H.C., CRUZ A.M.O., PAIVA A.D. 2011. Bacteriocin activity and resistance in livestock pathogens. In: Mendez-Vilas A. (Ed.), Science against microbial pathogens: communicating current research and technological advances, Formatex Microbiology Series No 3, Vol. 1, 853-863. ISBN-13: 978 84-939843-1-1.

MAQUEDA, M., SÁNCHEZ-HIDALGO, M., FERNANDEZ, M., MONTALBAN-LOPEZ, M., VALDIVIA, E., MARTINEZ-BUENO, M. 2007. Genetic features of circular bacteriocins produced by Gram-positive bacteria FEMS Microbiology Reviews, 32, 2-22. http://dx.doi.org/10.1111/j.1574 6976.2007.00087.x.

MARCISET, O., JERONIMUS-STRATINGH, M.C., MOLLE, B., POOLMAN, B. 1997. Thermophilin 13, a Nontypical Antilisterial Poration Complex Bacteriocin, That Functions without a Receptor. Journal of Biological Chemistry, 272(22), 14277-14284. http://dx.doi.org/10.1074/jbc.272.22.14277.

MATHOT, A.G., BELIARD, E., THUAULT, D. 2003. Streptococcus thermophilus 580 Produces a Bacteriocin Potentially Suitable for Inhibition of Clostridium tyrobutyricum in Hard Cheese. Journal of Dairy Science, 86(10), 3068-3074. http://dx.doi.org/10.3168/jds.S0022-0302(03)73906-X.

MONTESINOS, E. 2007. Antimicrobial peptides and plant disease control FEMS Microbiology Letters, 270(1), 1-11. http://dx.doi.org/10.1111/j.1574 6968.2007.00683.x.

MORAES P.M., PERIN L.M., ORTOLANI M.B.T., YAMAZI A.K., VIÇOSA G.N., NERO L.A. 2010. Protocols for the isolation and detection of lactic acid bacteria with bacteriocinogenic potential, LWT-Food Science and Technology, 43, 1320-1324. http://dx.doi.org/10.1016/i.lwt.2010.05.005

NISSEN-MEYER, J., OPPEGÅRD, C., ROGNE, P., HAUGEN, H.S., KRISTIANSEN, P.E. 2010. Structure and Mode-of-Action of the Two-Peptide (Class-IIb) Bacteriocins. Probiotics and Antimicrobial Proteins, 2, 52-60. http://dx.doi.org/10.1007/s12602-009-9021-z.

NOVOTNY, J.F., PERRY, J.J. 1992. Characterization of bacteriocins from Two Strains of Bacillus thermoleovorans, a Thermophilic Hydrocarbon-Utilizing Species. Applied and Environmental Microbiology, 58(8), 2393-2396.

ÖZDEMIR, G.B., BIYIK, H.H. 2011. Isolation and characterization of teobicin 218, a bacteriocin, produced by Geobacillus teobii HBB-218. African Journal of Biotechnology, 11(30), 7711-7719. http://dx.doi.org/10.5897/AJB11.1331.

PIPER, C., COTTER, P.D., ROSS, R.P., HILL, C. 2009. Discovery of Medically Significant Lantibiotics. Current drug discovery technologies, 6(1), 1-18. http://dx.doi.org/10.2174/157016309787581075.

PAIVA A.D., DE OLIVERA M.D., DE PAULA S.O., BARACAL-PEREIRA M.C., BEUKINK E., MONTAVANI H.C. 2012. Toxicity of bovicin HC5 against mammalian cell lines and the role of cholesterol in bacteriocin activity. Microbiology, 158, 2851-2858. http://dx.doi.org/10.1099/mic.0.062190-0

POKUSAEVA, K., KUISIENE, N., JASINSKYTE, D., RUTKIENE, K. SALEIKIENE, J., CHITAVICHIUS, D. 2009. Novel bacteriocins produced by Geobacillus stearothermophilus. Central European Journal of Biology, 4(2), 196-203. http://dx.doi.org/10.2478/s11535-009-0009-1.

ROSENBERG, I.M. 2005. Protein Analysis and Purification: Benchtop Techniques. 2nd ed., XXVI. Birkhäuser, Boston, USA, 546 p. ISBN 0-81764340-0 (hardcover), ISBN 0-8176-4341-9 (softcover).

SAMBROOK, J., RUSSELL, D.W (Ed.). 2001. Molecular cloning: A laboratory manual. 3rd ed. Cold Spring Harbor Laboratory Press, Cold Spring Harbor, New York. 2100 p. ISBN-10 0-87969-577-3, ISBN-13 978-0-87969-577-4.

SETTANNI, L., CORSETTI, A. 2008. Application of bacteriocins in vegetable food biopreservation. International Journal of Food Microbiology, 121, 123-138 http://dx.doi.org/10.1016/j.ijfoodmicro.2007.09.001.

SHARP, R.J., BINGHAM, H.A., COMER, M.J., ATKINSON, A. 1979. Partial Characterization of a Bacteriocin (Thermocin) from Bacillus stearothermophilus RS93. Journal of General Microbiology, 111, 449 451. http://dx.doi.org/10.1099/00221287-111-2-449.

SIT, C.S., VEDERAS, J.C. 2008. Approaches to discovery of new antibacterial agents based on bacteriocins. Biochemistry and Cell Biology, 86(2), 116-123 http://dx.doi.org/10.1139/O07-153.

STÅHL, R.S. 1991. Plasmids in Bacillus stearothermophilus coding for Bacteriocinogeny and Temperature Resistance. Plasmid, 26(2), 94 107. http://dx.doi.org/10.1016/0147-619X(91)90049-3. 
TIWARI, S.K., SRIVASTAVA, S. 2008. Purification and characterization of plantaricin LR14: a novel bacteriocin produced by Lactobacillus plantarum LR/14. Applied Microbiology and Biotechnology, 79(5), 759-767. http://dx.doi.org/10.1007/s00253-008-1482-6.

VERA PINGITORE, E., SALVUCCI, E., SESMA, F., NADER-MACÍAS, M.E.

2007. Different strategies for purification of antimicrobial peptides from Lactic Acid Bacteria (LAB), In: Mendez-Vilas A. (Ed.), Communicating Current Research and Education Topics and Trends in Applied Microbiology, Formatex, 557-568.

VILLANI, F., PEPE, O., MAURIELLO, G., SALZANO, G., MOSCHETTI, G., COPPOLA, S. 1995. Antilisterial activity of thermophilin 347, a bacteriocin produced by Streptococcus thermophilus. International Journal of Food Microbiology, 25(2), 179-190. http://dx.doi.org/10.1016/0168-1605(94)00153-W. YULE, R., BARRIDGE, B.D. 1976. Isolation and characterization of a bacteriocin produced by Bacillus stearothermophilus strain NU-10. Canadian Journal of Microbiology., 22(2), 1743-50. http://dx.doi.org/10.1139/m76-257. 